\title{
PÉCS TELEPHELYI TÉNYEZŐINEK VÁLLALATI MEGÍTÉLÉSE
}

\author{
Koltai Zoltán \\ egyetemi docens, Pécsi Tudományegyetem Kultúratudományi, Pedagógusképző és \\ Vidékfejlesztési Kar, koltai.zoltan@pte.hu
}

DOI: 10.15170/TVT.2022.07.01.04.

\begin{abstract}
Absztrakt
A kutatásunk által érintett 2004-2017 közötti időszakban jelentősen átalakult a magyar gazdaság növekedését meghatározó térségek köre. Míg 2007 elött elsődlegesen Budapest és vonzáskörzete felelt a gazdasági dinamizmusért, addig az ezt követő egy évtizedben mindez sokkal inkább volt köszönhető az erőteljes külföldi érdekeltségü feldolgozóiparral jellemezhető megyéknek. Ennek hátterében az országosan javuló foglalkoztatás mellett a munkatermelékenység utóbbi megyékben tapasztalható kedvező irányú folyamatai húzódtak meg, míg a központi régióban ezzel éppen ellentétes tendenciák körvonalazódtak. Tanulmányunk célja, hogy rétegzett kérdőíves megkeresések alapján (magyarországi vállalkozások régiók, vállalati méret és szektorok szerinti megoszlása) bemutassa a telephelyi tényezők magyarországi vállalati megítélését, jellemezze az értékelések időbeli változását. Vállalatokkal kapcsolatos, 2004-2005-ben lefolytatott kutatásunkat 2016-2017-ben ismételtük meg. Kérdöívünkben többek között az alábbiakra kerestünk választ: milyen szempontokat részesítenek előnyben a magyar vállalati szféra szereplöi telephelyük megválasztásakor, melyik magyarországi településeket, és miért tartják sikeresnek a vállalatvezetők?
\end{abstract}

Kulcsszavak: sikeresség, telephelyi tényezök, vállalatok, Magyarország, Pécs

\section{JUDGEMENT OF THE LOCATION FACTORS OF PÉCS BY BUSINESSES}

\begin{abstract}
In the 2004-2017 period, the focus of our research, the circle of regions determining the growth of the Hungarian economy went through a significant transition. While it had been Budapest and its hinterland that were the main source of economic dynamism before 2007, in the decade after that it was much more the counties with strong foreign-based manufacturing industry that were responsible for the growth. In the background of this we find, in addition to the nationally improving employment conditions, the favourable processes in the improvement of the work productivity typical in these counties, while in the central region tendencies just the opposite to this unfurled. The aim of the paper is to demonstrate, using a layered questionnaire survey (breakdown of Hungarian enterprises by region, company size and sectors) the judgement of the location factors by the Hungarian economic actors and describe the change of evaluations over time. The research we had conducted with companies in 2004-2005 was repeated in 20162017. In our questionnaire we focused among others on the following issues: what aspects do Hungarian businesses prefer when choosing their business location, which Hungarian cities are considered successful by company leaders and why?
\end{abstract}

Keywords: successfulness, location factors, businesses, Hungary, Pécs 


\section{Bevezetés}

A magyar települések telephelyi sikerességét mára elsősorban belső adottságaik határozzák meg. A településhierarchiában elfoglalt pozíció, a közigazgatási szerepkör mellett (de nem helyett) meghatározó faktorrá gazdasági adottságaik, jövedelemszerzési lehetőségeik váltak. A közszolgáltatásokkal szemben megerősödött a piaci alapú tevékenységek, föként a modern üzleti szolgáltatások magyarázó ereje. Az előzőkkel szoros összefüggésben felértékelődött a települések földrajzi elhelyezkedése, megközelíthetőségük (BAKOS - HIDAS - KEZÁN 2011), környezeti állapotuk (MAKRA - SÜMEGHY 2010), történelmi-kulturális adottságaik (BERKI - GONDA 2006, BARANYAI - BARÁTH 2009, PAP - GONDA - RAFFAY 2013), humán erőforrásaik képzettsége, az innovációt hordozó intézmények jelenléte (RECHNITZER - CSIZMADIA - GROSZ 2004, LENGYEL 2012, KONCZOSNÉ SZOMBATHELYI 2014) és nem utolsósorban a helyi fejlesztéspolitika aktivitása (ENYEDI 1996, RECHNITZER 1998, LENGYEL - RECHNITZER 2000). Mindez a tercier vállalkozások rugalmasabb telephelyválasztásán keresztül még több település számára tette lehetővé a gazdasági folyamatokba történő aktív bekapcsolódást. A rendszerváltozással párosuló lehetőségeket azokban a térségekben tudták a legjobban kihasználni, ahol a képzett népesség gazdasági előnnyé tudta alakítani felhalmozott szellemi-kulturális és kapcsolati-információs tőkéjét. Amennyiben ezek a tényezők egy térségben viszonylag kedvező infrastrukturális adottságokkal párosultak, szinte biztos volt a kedvező irányú folyamatok beindulása (SZAKÁLNÉ KANÓ - KAZEMI-SÁNTA - LENGYEL 2017, SZIRMAI 2017, RECHNITZER - BERKES - FILEP 2019). A nyertesek azok a közép- és nagyvárosok lettek, melyek nem csak nagyobb népességgel és vonzáskörzettel, de többszintü, részben piacgazdasági intézményrendszerrel és magasabb jövedelemtermelö képességgel is rendelkeztek, térségi hatásuk új, alapvetően fogyasztásra épülő dimenzióval szélesedett az elmúlt évtizedekben. Amellett, hogy ehhez a településszinthez eleve kedvezőbb induló gazdasági feltételek párosultak, fejlett általános és humán infrastruktúrájuk okán a külföldi működőtőke is főként rájuk koncentrált (NAGY 1995, BARTA 2000, HRUBI 2000). A versenyképesség továbbra is erős hierarchikus meghatározottsága okán ezzel együtt kijelenthető, hogy közép- és nagyvárosaink vonzása részben ellensúlyozhatja kedvezőtlen földrajzi fekvésüket. A kis- és közepes méretű városok ugyan sem humán-, sem intézményi adottságaikat tekintve nem rendelkeznek nagyvárosi feltételekkel, de a tartós gazdasági növekedést mutató régiókban egy hálózat részeként ezek is fejlesztőleg hathatnak környezetükre (HARCSA 2015, RECHNITZER 2019).

Tanulmányunk célja, hogy a megismételt, rétegzett kérdőíves megkeresések alapján bemutassuk a magyarországi települések telephelyi megítélését és jellemezzük azok időbeli változását, kiemelt figyelmet fordítva ezúttal Pécs városára.

\section{Kutatási eredmények}

Vállalatokkal kapcsolatos, 2004-2005-ben lefolytatott kutatásunkat (KOLTAI 2006, 2007) 2016-2017-ben ismételtük meg (KOLTAI 2019, KOLTAI - FILÓ 2021a, b). A rétegzett kérdőíves megkeresések (magyarországi vállalkozások régiók, vállalati méret és szektorok szerinti megoszlása) eredményeként ismét ezer vállalkozó, vállalatvezető adott választ kérdéseinkre. A vállalkozások földrajzi megoszlását alapul véve, 40 \% feletti arányban a középmagyarországi régióból kerültek ki a válaszadók, a többi régiót 8-12\% közötti arányban képviselték a megkérdezettek. Vállalati méret szerint a mikro- és kisvállalatok $96 \%$ feletti arányban szerepelnek mintánkban. A tercier ágazat képviselői közel 80\%-os előfordulással képezték le a vállalati populációt, az iparvállalatok 17,5, az agrárvállalkozások 3,5\%-os részarányt képviseltek. A személyes lekérdezéseknek köszönhetően a kitöltött kérdöívek szinte kivétel nélkül alkalmasak voltak a kiértékelésre. Kérdőívünkben három zárt, három nyitott és egy félig zárt, összesen hét kérdés keretében az alábbi témakörökre kerestünk választ: 
- Milyen szempontokat részesítenek előnyben a magyar vállalati szféra szereplői telephelyük megválasztásakor?

- Melyik magyarországi településeket, és miért tartják sikeresnek a vállalatvezetők?

- Melyek azok a települések, melyeket valódi gazdasági központoknak tartanak az érintettek?

- Milyen belföldi és nemzetközi mobilitási hajlandóság jellemzi a magyar vállalkozásokat?

- Melyek az előnyei, illetve hátrányai a különböző településtípusokon történő vállalati müködésnek?

A tanulmány további részeiben részletesen megismertetésre kerülö hipotéziseink az alábbiakban foglalhatók össze:

- A sikeresnek gondolt telephelyek élmezőnyébe nagyvárosokat, régió- és megyeközpontokat vártunk, köztük Péccsel. A város relatív pozíciójában inkább stagnálást, kismértékü visszaesést feltételeztünk.

- Második hipotézisünk értelmében a sikeresség mögöttes tényezői alapján jelentős differenciák mutatkoznak a részletes elemzésnek alávetett városok vonatkozásában. A legsokrétübb magyarázatokat a telephelyi rangsor élén található városok esetében vártuk. Pécs elsősorban képzett munkaerejének, környezeti minőségének és innovációs kultúrájának köszönheti kedvezö megítélését.

- A vállalatvezetők valamennyi régióban meghatározó központként tekintenek Budapestre. Számítottunk Győr és Kecskemét központi szerepkörének országos felértékelődésére, míg Pécs megítélése elsősorban a Dél-Dunántúlon számít kedvezőnek.

\subsection{A telephelyi tényezök vállalati megítélése}

Az első kérdés keretében arra kerestünk választ, hogy az általunk kiválasztott telephelyi tényezök mennyire fontosak a müködési helyszín kijelölésekor. Az alábbi tizenkét szempont értékelésére kértük a válaszadókat, ötfokozatú skálát alkalmazva:

1. a település gazdasági szerkezete (ágazati szerkezet, kapcsolódó iparágak, beszállítói kapcsolatok, háttéripar fejlettsége)

2. a település innovációs kultúrája, szellemi tőkepotenciálja (kutatás-fejlesztési kapacitások, felsőfokú oktatási intézmények, kutatóintézetek léte)

3. a regionális elérhetőség, a település földrajzi fekvése (közlekedési infrastruktúra, Budapest megközelíthetősége)

4. a müködéssel kapcsolatos költségek (munkabérek, adók, adókedvezmények)

5. a helyi önkormányzat aktivitása, településpolitikája (befektetés ösztönzés, városmarketing, ügyintézés menete, konfliktuskezelés módja)

6. a település környezeti minősége (lakóhelyi adottságok, természeti és épített környezet, szabadidős, egészségügyi és oktatási intézmények)

7. a település közintézményekkel való ellátottsága (közszolgáltatások, hivatalok müködése)

8. a település üzleti szolgáltatásai (bankhálózat, ipari park, vállalkozásfejlesztési iroda müködése)

9. a munkaerő felkészültsége és hatékonysága (iskolai végzettség, nyelvismeret, munkatermelékenység, munkaerő-piaci adatok)

10. a település, mint felvevőpiac (piacméret, fogyasztói potenciál, vonzáskörzet jelleg) 
11. a település demográfiai és társadalmi adottságai (korszerkezet, migrációs folyamatok, népsürüség)

12. a település nemzetközi kapcsolatrendszere (külföldi érdekeltségü vállalkozások és beruházások, testvérvárosi kapcsolatok, turizmus)

Megelőző kutatásunk szempontrendszerét két új tényezővel (demográfiai és társadalmi adottságok, a település nemzetközi kapcsolatrendszere) egészítettük ki, ezzel is tovább árnyalva a válaszadási lehetőséget.

2004-2005-ös kutatásunk válaszadói első helyre a település regionális elérhetőségét, földrajzi fekvését sorolták, amit valamivel elmaradva a felvevőpiaci jelleg követett (KOLTAI 2006, 2007, 2014). A következö, közepesre értékelt tényezőcsoportot az üzleti szolgáltatások, a település gazdasági szerkezete, a müködési költségek, a munkaerő képzettsége és a közintézményi ellátottság alkották. Sorrendben a környezeti minőség és a helyi önkormányzat településpolitikája következett, a legalacsonyabb értéket pedig a település innovációs kultúrája kapta. Újabb kutatásunk eredményei alapján a rangsor első helyére már a müködéssel kapcsolatos költségek kerültek, amit a település regionális elérhetősége és a felvevőpiaci jelleg követ (1. ábra). A következő csoportot a munkaerő felkészültsége és hatékonysága vezeti, megelőzve a település gazdasági szerkezetét, az üzleti szolgáltatásokat, a helyi önkormányzat településpolitikáját, a környezeti minőséget és a közintézményi ellátottságot. Továbbra is az alacsonyabbra értékelt tényezők körében szerepel az innovációs kultúra, ahogy szintén a lista végén találjuk mindkét új szempontunkat, a demográfiai-társadalmi adottságokat és a település nemzetközi kapcsolatrendszerét.

1. ábra: A telephelyi tényezők fontossági sorrendje a magyar vállalatok megkérdezése alapján, 2004/2005-2016/2017 (n=1000)

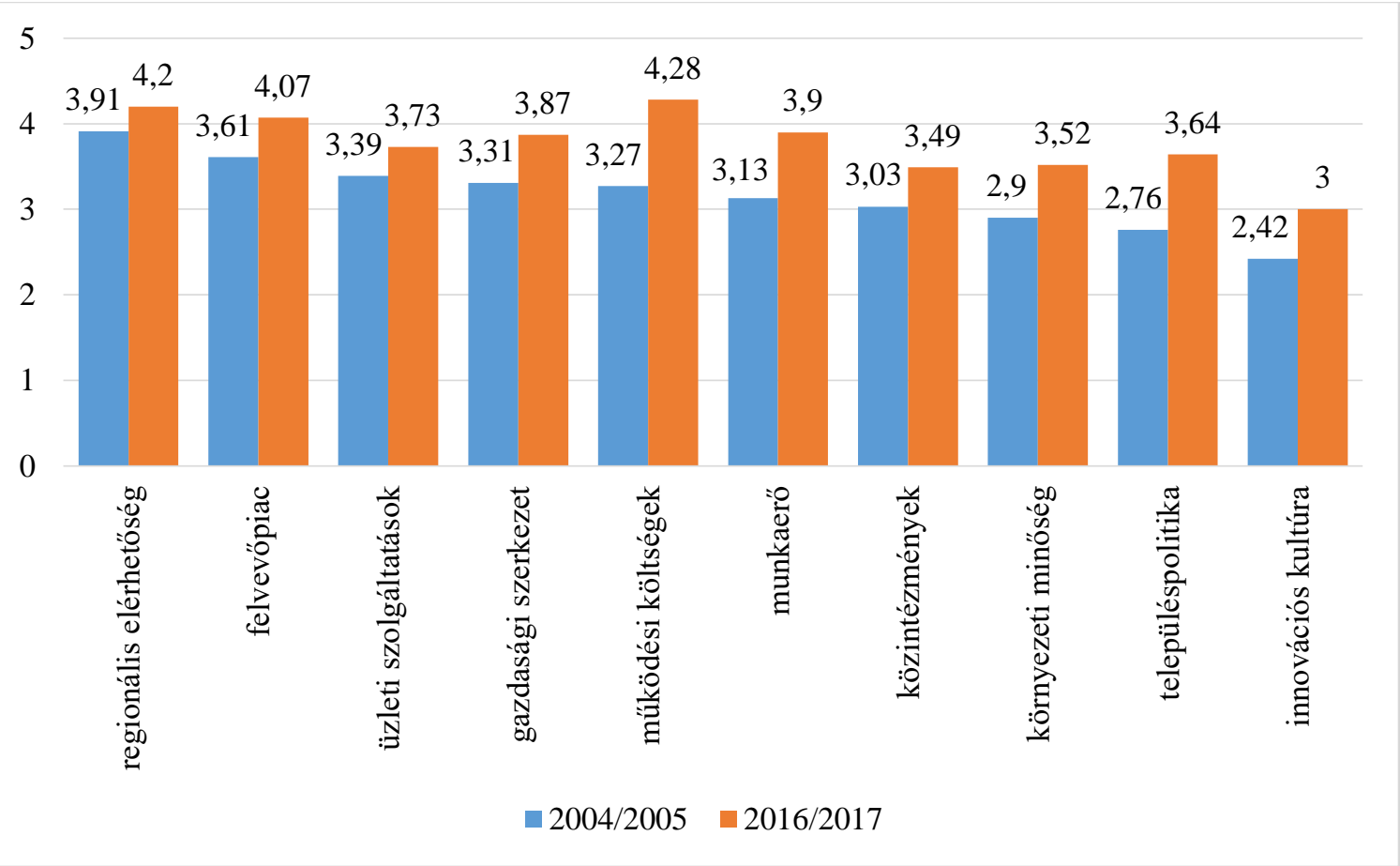

Forrás: Saját kérdölves felmérés (2004-2005, 2016-2017)

Korábbi tényezőink kivétel nélkül magasabb pontértéket kaptak. Közülük az átlagosnál nagyobb mértékben nőtt a helyi önkormányzat településpolitikájának, a müködési költségeknek, a munkaerő felkészültségének, a település innovációs kultúrájának és a környezeti minőségnek a magyarázó ereje. Kijelenthető, hogy a magyar vállalkozások egyrészt 
költségérzékenyebbé váltak a vizsgált bő tíz évben, másrészt fontosabbá vált számukra a felkészült és hatékony munkaerő megléte vagy éppen annak hiánya. Ha figyelembe vesszük a munkaképes korú népesség (15-64 évesek) létszámának országos csökkenését, mely alól egyedül Közép-Magyarország jelent kivételt a vizsgált másfél évtized viszonylatában, bátran kijelenthető, hogy a kvalifikált munkaerő megszerzése egyre komolyabb kihívások elé állítja a magyar vállalkozásokat (LENGYEL - VARGA 2018). A települések innovációs kultúrájának felértékelődését erősíti az a tény, hogy a két adatfelvétel viszonylatában kismértékü kiegyenlítődés figyelhető meg az egy lakosra jutó $\mathrm{K}+\mathrm{F}$ beruházások megyei értékeiben. Mindez elsősorban Közép-Magyarország hátrányára és a jelentősebb külföldi érdekeltségü feldolgozóiparral rendelkező vidéki megyék elönyére történt. RECHNITZER (2019) a megyei jogú városok fejlesztési stratégiáit elemezve kiemeli az innováció és a szellemi erőforrások elmúlt években tapasztalt felértékelödését.

\subsection{Országos és regionális telephelyi sorrendek}

Kérdöíves adatfelvételünk második kérdése során arra kértük a vállalkozások vezetőit, hogy saját tapasztalatuk tükrében sorolják fel a leginkább sikeresnek gondolt magyarországi településeket és az általunk megadott 12 telephelyi tényező segítségével indokolják is döntésüket. (Mivel Budapest gazdasági értelemben (is) külön kategóriát képvisel a hazai városhálózatban, ezért a fővárost nem szerepeltettük a kutatás ezen részében.)

Mivel megelőző kutatási eredményeink kizárólag közép- és nagyvárosokat nevesítettek a leginkább sikeresnek gondolt telephelyek között (KOLTAI 2006, 2007, 2014), valamint ezek gazdasági növekedése közismerten jóval dinamikusabb, mint a kisvárosoké vagy falvaké, elsö hipotézisként nagyvárosokat, elsősorban Győrt, Székesfehérvárt, valamint Sopront vártuk az élmezőnybe. Kecskemét tíz év alatt megfigyelhető jelentősebb felértékelödését prognosztizáltuk, Pécs esetében viszont inkább stagnálást, kismértékü visszaesést feltételeztünk.

Aktuálisan kapott adataink szerint (1. táblázat) Győr kiemelkedik a vidéki települések sorából, melyet Debrecen és Székesfehérvár követ. Bár Győr impozáns módon már a 2004-2005-ös adatfelvétel során a válaszok közel $62 \%$-ában szerepelt, mindez aktuálisan $70 \%$ feletti gyakoriságra emelkedett. Debrecen esetében ennél is jelentősebb mértékben, közel másfélszeresére növekedett azon válaszadók számát, akik ma sikeres telephelyként tekintenek a városra, Székesfehérvár értéke viszont kismértékben $(-6,7 \%$-kal) visszaesett. Szeged alig lemaradva került a negyedik helyre, megelőzve Kecskemétet, Pécset és Sopront. Az alföldi városokat aktuálisan jóval kedvezőbben értékelik a megkérdezett vállalkozások (Kecskemét 2,5-szeres, Szeged 1,5-szeres értéke a két legdinamikusabb növekedést jelzi), Pécs említése kismértékben $(9,8 \%)$ nőtt, míg a Sopront említő válaszok közel 21\%-kal csökkentek. Jelentősebb lemaradással Szombathely következik (-29,9\%), majd Nyíregyháza $(-2,4 \%)$, Miskolc (-12,9\%), Veszprém $(-14,3 \%)$ és Budaörs (+33,3\%) szerepel minimális differenciákkal. Utóbbi város az egyetlen új szereplöje az 5\%-os említési küszöböt meghaladó települési körnek. (Mindezt jól alátámasztja Budaörs helyi foglalkoztatási szerepkörének elmúlt évekbeli kedvező irányú változása (KISS - SZALKAI 2014, PÉNZES - MOLNÁR PÁLÓCZI 2014). A város kiemelkedően kedvező gazdasági reziliencia értékeire hívja fel a figyelmet SEBESTYÉNNÉ SZÉP et al. 2020). A korábbi élmezőny tagjai közül Zalaegerszeg és Kaposvár lekerültek a jelenlegi listáról. Mindkét város esetén hozzávetőleg megfeleződött ($43,1 \%$, illetve $-52,8 \%$ ) azon válaszadók száma, akik sikeres telephelyként tekintenek rájuk. (Kaposvár értékei a dél-dunántúli rangsorban is jelentős pozícióvesztést mutatnak a tíz évvel korábbi válaszokhoz mérten. A régió térszerkezetét és strukturális sajátosságait részletesen elemzi MÁTÉ (2017). Közel két évtizedes tendenciák elemzésére nyílik lehetőség KOZMA (1998) magyarországi települések gazdasági alkalmasságát elemző kutatása tükrében. Győr már ekkor az első helyen szerepelt, ahogy újabb kutatásunk legjobbra értékelt 12 városa közül 
a nyugati országrészben található települések szintén mindannyian már az akkori élmezőny tagjai voltak. A vállalkozások szerint Kelet-Magyarország reprezentánsai akkor még rosszabb feltételeket kínáltak. Magyarországi gazdasági centrumokat értékelő kutatásukban NAGY NAGY (2008) szintén Györt nevesíti legerősebb vidéki központként, Székesfehérvárt és Szombathelyt megelőzve, az élmezőny tagjai ekkor is megegyeznek 2004-2005-ös kutatási eredményeinkkel.) A városok sorrendbeli elmozdulását a megyei GDP/lakos adatok változása is jól alátámasztja. Két adatfelvételünk közötti időpontban (2004/2005-2016/2017) a legdinamikusabb növekedést Győr-Moson-Sopron és Bács-Kiskun megyék mutatják, megelőzve a listánkra települést nem delegáló Tolna megyét. Ugyanezen időszak leggyengébb adataival Nógrád, Baranya és Zala megye rendelkezik (LENGYEL - VARGA 2018). Szintén a pozícióváltozások tendenciajellegére hívja fel a figyelmet CSOMÓS (2013) településgazdasági súly alapú rangsorában, jól érzékeltetve többek között Budaörs elöre lépését vagy éppen Pécs folytatólagos lemaradását. ${ }^{15}$

1. táblázat: A telephelyek sorrendje a magyar vállalatok megkérdezése alapján, 2016-2017 $(n=1000)$

\begin{tabular}{|l|l|l|l|}
\hline Ssz. & Település & $\begin{array}{l}\text { Említések } \\
\text { száma }\end{array}$ & $\begin{array}{l}\text { Változás mértéke } \\
(2004 / 2005 \\
100)\end{array}$ \\
\hline 1. & Györ & 707 & $+14.8 \%$ \\
\hline 2. & Debrecen & 382 & $+45,2 \%$ \\
\hline 3. & Székesfehérvár & 360 & $-6,7 \%$ \\
\hline 4. & Szeged & 344 & $+52,2 \%$ \\
\hline 5. & Kecskemét & 324 & $+163,4 \%$ \\
\hline 6. & Pécs & 269 & $+9,8 \%$ \\
\hline 7. & Sopron & 235 & $-20,9 \%$ \\
\hline 8. & Szombathely & 108 & $-29,9 \%$ \\
\hline 9. & Nyíregyháza & 81 & $-2,4 \%$ \\
\hline 10. & Miskolc & 81 & $-12,9 \%$ \\
\hline 11. & Veszprém & 66 & $-14,3 \%$ \\
\hline 12. & Budaörs & 64 & $+33,3 \%$ \\
\hline & Forrás: Saját kérdöives felmérés $(2016-2017)$ \\
\hline
\end{tabular}

Természetesen ezúttal is lehetőségünk nyílt a reprezentativitást biztosító szempontok, így a földrajzi elhelyezkedés, a vállalati méret és az ágazati besorolás szerint további elemzésekre, melyek közül ezúttal kizárólag a Pécs vonatkozásúakat érintjük. Ahogy korábbi vizsgálatunk során, úgy most is egyetlen régióban fordult elö, hogy nem Győrt említették a legversenyképesebb településnek. (Tíz évvel korábban az Észak-Alföldön került a rangsor élére Debrecen. Aktuálisan a közép-dunántúli vállalkozások gondolták ugyanezt Székesfehérvárról.) A dél-dunántúli vállalatok közel kétszer annyian említik Győrt, mint a régiót képviselő,

\footnotetext{
15 További sorrend a legalább 2\%-os említési határt elért településeknél: Eger, Tatabánya, Siófok, Zalaegerszeg, Dunaújváros, Szolnok, Érd, Hévíz, Kaposvár, Gödöllő, Esztergom. (Ezen másodlagos vidéki szintnek minősülő településeket tipizálja CSOMÓS (2013) a helyben müködő gazdasági szervezetek pénzügyi adatai alapján, megkülönböztetve azok fövárosi agglomerációs, tradicionális iparközpont, új gazdasági központ vagy idegenforgalmi jellegét.)
} 
második helyezett Pécset. Az 5\%-os említés feletti települések rangsorát az országos listán hátrébb szereplő régióbeli városok, Kaposvár, Siófok, Szekszárd és Paks zárják a dél-dunántúli válaszadók szerint.

Amennyiben az ágazati megoszlás szerinti listákat elemezzük, kijelenthető, hogy még inkább kiemelkedik Győr, jobb pozíciót ér el Kecskemét, Székesfehérvár és Veszprém, valamint megjelenik Tatabánya, Zalaegerszeg, Dunaújváros és Érd is az iparvállalati rangsorban. Ezzel szemben kedvezőtlenebb Szeged, Pécs és részben Sopron iparvállalati megítélése. Az agrárvállalkozások szerint Székesfehérvár, Debrecen és Kecskemét megítélése előnyösebb, valamint ekkor Zalaegerszeg és Szolnok is tagja a legsikeresebb telephelyek csoportjának. A mezőgazdasági válaszadók ellenben jelentősen rontanak Sopron, kisebb mértékben Pécs megítélésén. (Mindezt jól alátámasztja az ipari vállalkozások nagyobb arányú jelenléte Kecskeméten, Székesfehérváron, Győrben és Nyíregyházán, valamint a mezőgazdasági vállalkozások gyakoribb előfordulása Debrecen és Kecskemét gazdasági szerkezetében. MOLNÁR et al. 2018).

Hipotézisünk teljesült, miszerint csakugyan nagyvárosok, főként régió- és megyeközpontok kerültek az országos rangsor élére. Pécs stagnál, korábbi pozícióján egy helyet rontva, országosan a hatodik legtöbb említést kapta. Több alföldi nagyváros (elsősorban Debrecen és Szeged) az általunk vártnál jobb pozíciót birtokol. (Érdekes összehasonlításokra nyújt lehetőséget EGEDY (2012) magyar nagyvárosok versenyképességére elvégzett kutatása. A szerző eredményei kiválóan előre jelzik az általunk tapasztalt változások irányát. Győr, Debrecen és Székesfehérvár stabil gazdasági központként müködését részletesen elemzi Rechnitzer (RECHNITZER - PÁTHY - BERKES 2014, RECHNITZER 2019). MOLNÁR et al. (2018) kutatási eredményei szintén megerősítik Debrecen többi régióközpontot meghaladó, dinamikus fejlődését, ahogy Pécs gazdasági dinamikájának hanyatlását is. DÖBRÖNTE (2018) szintén Debrecent nevesíti nemzetközi gazdasági áramlásokba potenciálisan bekapcsolódó helyszínként.)

\subsection{A magyarországi települések telephelyi vonzerejének megítélése}

A településfejlesztési elképzelések számára hasznos információval szolgálhat kutatásunk azon része, amikor arról kérdeztük a vállalatokat, milyen mögöttes okok miatt tartanak sikeres telephelynek egy adott települést. Részletes elemzésre az 5\%-os említési küszöböt meghaladó 12 település esetében vállalkoztunk, az egyes települések fejlődési sajátosságainak értékeléséhez kétféle szempontot követtünk:

1. relatív térbeni összehasonlításokat végeztünk a 2016-2017-es adatfelvétel időpontjára értelmezve,

2. a mutatószámok abszolút értékeinek időbeni változását is vizsgáltuk a megelőző kutatás 2004-2005-ös bázisadataihoz viszonyítva.

Amennyiben valamennyi telephelyi tényezö esetében összehasonlítjuk az említett településeket, jól megmutatkoznak bizonyos pozitív (és persze negatív) irányú elmozdulások a rangsorokban, kirajzolva ezzel az egyes települések karakteres jegyeit, illetve meglévő hiányosságaikat. A függőleges tengelyen (2., 3. ábra) az egyes tényezők versenyképesség magyarázaton belüli százalékos előfordulását szerepeltetjük, külön jelölve az adott tényező 12 városra értelmezett átlagértékét. (Hangsúlyozni szeretnénk, hogy az átlag a legsikeresebbnek gondolt 12 település adataiból áll elő, így az semmiképpen sem értelmezhető valamennyi magyarországi településre.) Az átlag feletti érték ebben az értelemben arra hívja fel a figyelmet, hogy az adott telephelyi tényező a többi városhoz képest karakteresebben jelenik meg a település sikerességének magyarázatai között. Úgy véljük, minél több telephelyi tényező kapcsán tud egy adott település átlagot meghaladó értékü, markáns jellemvonást felmutatni, 
annál megalapozottabbnak számít versenyképessége. Második hipotézisünk értelmében a sikeresség mögöttes tényezői alapján jelentős differenciák mutatkoznak a részletes elemzésnek alávetett városok vonatkozásában, a legsokrétűbb magyarázatokat a rangsor élén található városok (Győr, Székesfehérvár, Sopron) esetében vártuk, míg Pécs elsősorban képzett munkaerejének, környezeti minőségének és innovációs kultúrájának köszönheti kedvező megítélését.

1. a település gazdasági szerkezete (ágazati szerkezet, kapcsolódó iparágak, beszállítói kapcsolatok, háttéripar fejlettsége): Győr, Székesfehérvár, Kecskemét és Budaörs emelkednek ki az átlagból (2. ábra).

2. a település innovációs kultúrája, szellemi tőkepotenciálja (kutatás-fejlesztési kapacitások, felsőfokú oktatási intézmények, kutatóintézetek léte): Győr, Szeged és Pécs értéke haladja meg az átlagot (3. ábra).

3. regionális elérhetőség, a település földrajzi fekvése (közlekedési infrastruktúra, Budapest megközelíthetősége): Győr, Székesfehérvár, Kecskemét, Sopron és Budaörs értékei emelkednek ki.

4. a müködéssel kapcsolatos költségek (munkabérek, adók, adókedvezmények): nyolc város is pozitív irányban tünik ki (Debrecen, Székesfehérvár, Szeged, Kecskemét, Szombathely, Nyíregyháza, Miskolc és Budaörs).

5. a helyi önkormányzat aktivitása, településpolitika (befektetés ösztönzés, városmarketing, ügyintézés menete, konfliktuskezelés módja): Győr, Debrecen és Budaörs az átlagot meghaladó pozitív példa.

2. ábra: A települések gazdasági szerkezetének megítélése, 2016-2017 (n=1000)

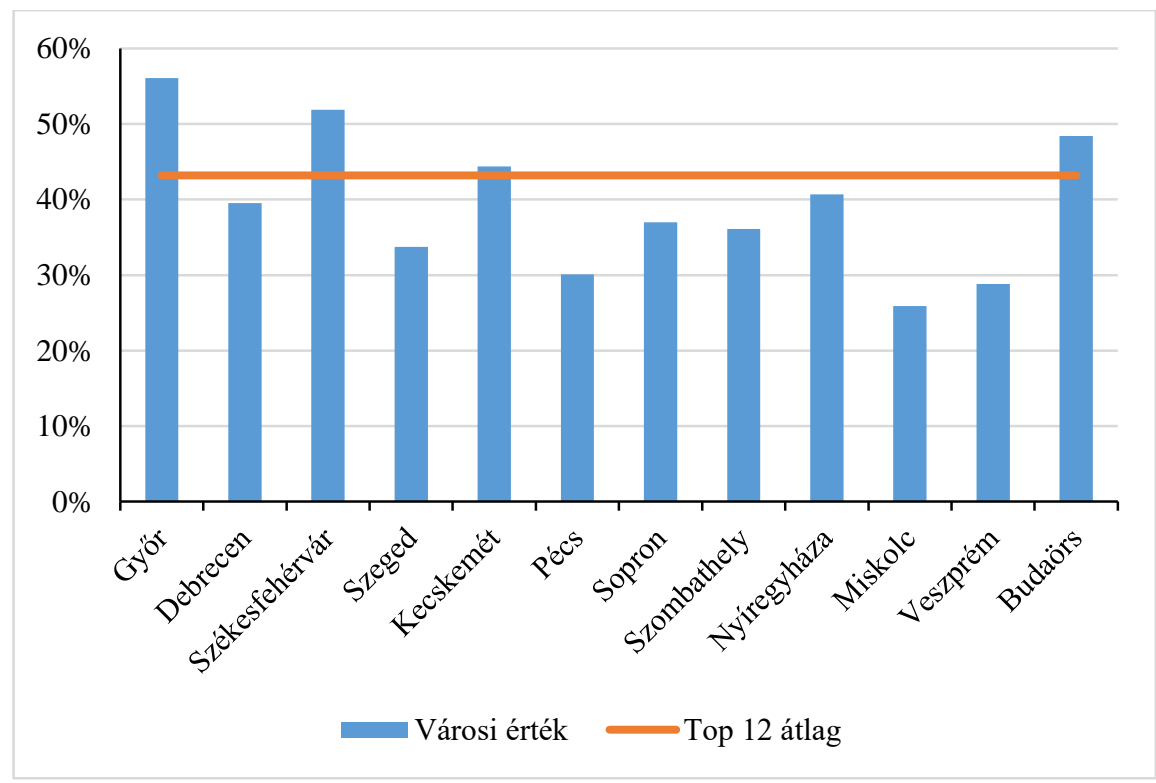

Forrás: Saját kérdöives felmérés (2016-2017)

6. a település környezeti minősége (lakóhelyi adottságok, természeti és épített környezet, szabadidős, egészségügyi és oktatási intézmények): Győr, Pécs, Sopron és Veszprém rendelkezik a legkedvezőbb értékekkel.

7. a település közintézményekkel való ellátottsága (közszolgáltatások, hivatalok müködése): az átlagot jelentősen meghaladó értékkel jellemezhető Debrecen, Szeged, Pécs, Nyíregyháza és Veszprém. 
8. a település üzleti szolgáltatásai (bankhálózat, ipari park, vállalkozásfejlesztési iroda müködése): az élmezőny tagja Győr, Székesfehérvár, Sopron, Veszprém és Budaörs.

9. a munkaerő felkészültsége és hatékonysága (iskolai végzettség, nyelvismeret, munkatermelékenység, munkaerő-piaci és munkanélküliségi adatok): kiemelkedik Győr, Székesfehérvár, Kecskemét, Szombathely és Veszprém értéke.

3. ábra: A települések innovációs kultúrájának megítélése, 2016-2017 (n=1000)

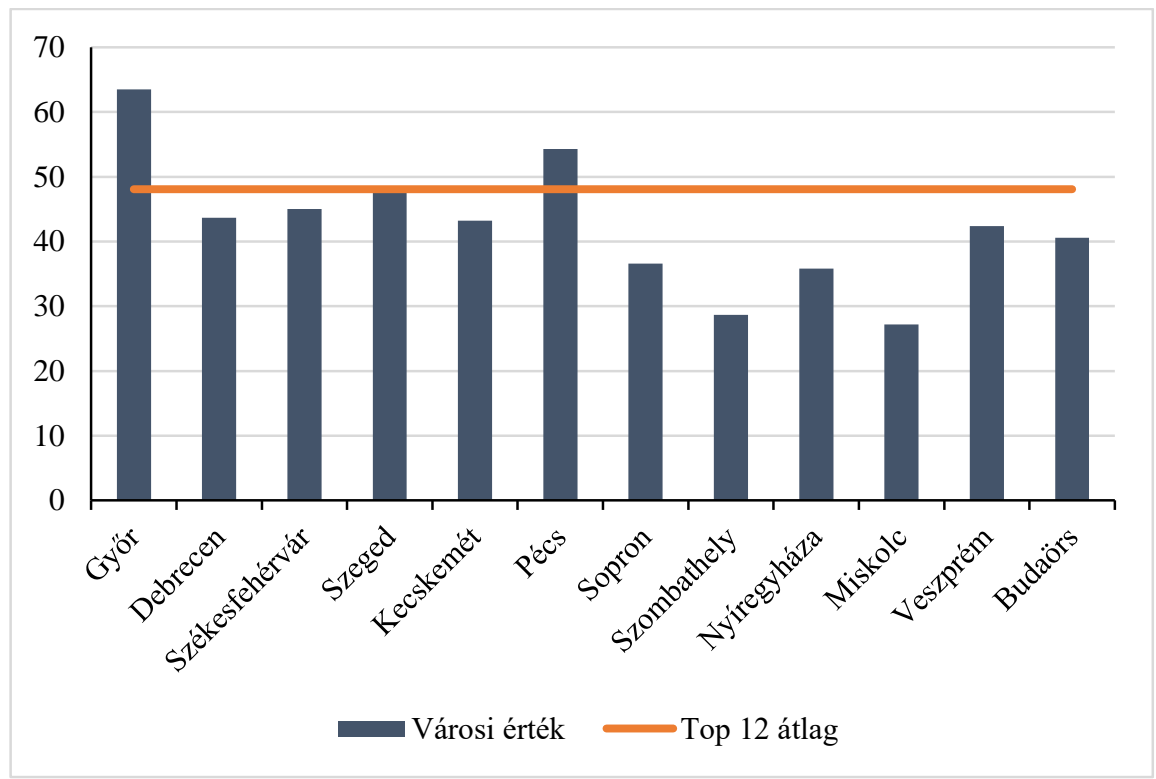

Forrás: Saját kérdőives felmérés (2016-2017)

10. a település, mint felvevöpiac (piacméret, fogyasztói potenciál, vonzáskörzet jelleg): az átlagot jóval meghaladó értékkel bír Győr, Sopron és Budaörs.

11. a település demográfiai és társadalmi adottságai (korszerkezet, migrációs folyamatok, népsürüség): Győr, Szeged, Sopron, Szombathely, Veszprém és Budaörs értéke átlag feletti.

12. a település nemzetközi kapcsolatrendszere (külföldi érdekeltségü vállalkozások és beruházások, testvérvárosi kapcsolatok, turizmus): Győr és Sopron mutat kiemelkedő értéket ebben a dimenzióban.

Összefoglalva az egyes városok átlagot meghaladó vagy attól lényegesen elmaradó értékeit, az alábbi kijelentéseket tehetjük:

- Győr 10 tényező esetében is átlagot meghaladó értékkel jellemezhető, ami jól alátámasztja a város sokrétü versenyképességét. Mindössze a müködési költség az a telephelyi tényező, amely a többi városhoz képest kevésbé domináns, a város közintézményekkel való ellátottságát pedig átlagos gyakorisággal említik a válaszadók a magyarázatok sorában.

- Debrecen 3 tényező esetében mutat kimagasló értéket (müködéssel kapcsolatos költségek, helyi önkormányzat aktivitása, közintézményi ellátottság), ezzel szemben 2 olyan tényezőt találunk (regionális elérhetőség, nemzetközi kapcsolatrendszer), amely az átlagosnál jóval ritkábban fordul elő a sikeresség indokai között. (DÖBRÖNTE (2018) némileg ellentmondva eredményeinknek Debrecent nevesíti a nemzetközi gazdasági áramlásokba potenciálisan bekapcsolódó elsődleges vidéki helyszínként.)

- Székesfehérvár érdekessége, hogy miközben 5 tényező esetében is kiemelkedik (gazdasági szerkezet, regionális elérhetőség, müködési költségek, üzleti szolgáltatások, munkaerő 
felkészültsége) egyedüliként a részletes vizsgálat alá vont tizenkét városból, egyetlen tényező kapcsán sem mutat jelentős elmaradást az átlagértékektől.

- Szeged és Kecskemét esetében is 4-4 kimagasló, tartalmában különböző tényezővel szemben (Szeged: innovációs kultúra, müködési költségek, közintézményi ellátottság, demográfiai és társadalmi adottságok, Kecskemét: gazdasági szerkezet, regionális elérhetőség, müködési költségek, munkaerő felkészültsége) mindössze 1 tényező (üzleti szolgáltatások) fordul elö az átlagosnál lényegesen ritkábban a magyarázatok sorában. (Kecskemét kapcsán VARGA - TEVELI-HORVÁTH - SALAMIN (2020) a város fiatal, kreatív lakosságot vonzó potenciálját hangsúlyozza.)

- Pécs 3 tényező kapcsán (innovációs kultúra, környezeti minőség, közintézményekkel való ellátottság) emelkedik ki, 2 tényező (gazdasági szerkezet és regionális elérhetőség) előfordulása viszont a többi városhoz képest kevésbé meghatározó magyarázat.

- Sopron a harmadik legtöbb, egész pontosan 6 tényező kapcsán (regionális elérhetőség, környezeti minőség, üzleti szolgáltatások, felvevőpiac, demográfiai és társadalmi adottságok, nemzetközi kapcsolatrendszer) emelkedik az átlagérték fölé és mindössze 1 tényező esetében (müködési költségek) jelez lényeges elmaradást attól. (Sopron munkaerőpiaci szerepkörének átalakulását részletesen elemzi KISS et al. 2018.)

- Szombathely kapcsán 3 kiemelkedő tényezővel (müködési költségek, munkaerö felkészültsége, demográfiai és társadalmi adottságok) szemben 1 elmaradó tényező (innovációs kultúra) áll.

- Nyíregyháza esetében a 2 kiemelkedő tényezőt (müködési költségek, közintézményi ellátottság) már 3 átlagértéktől elmaradó szempont (munkaerő felkészültsége, demográfiai és társadalmi adottságok, nemzetközi kapcsolatrendszer) egészít ki.

- Miskolcot mindössze 1 tényező (müködéssel kapcsolatos költségek) emeli az átlag fölé, ezzel szemben 9 olyan tényezőt is beazonosíthatunk, melyek az átlagosnál jóval ritkábban szolgálnak a sikeresség indokaként.

- Veszprém 5 tényező esetében is kiemelkedik (környezeti minőség, közintézményi ellátottság, üzleti szolgáltatások, munkaerő felkészültsége, demográfiai és társadalmi adottságok) és csupán 1 tényezőben (gazdasági szerkezet) marad el lényegesen az átlagértéktől.

- Budaörs a második legtöbb, összesen 7 tényező esetében átlagot meghaladó értéket jelez, ezzel szemben 2 olyan tényező van (közintézményi ellátottság, nemzetközi kapcsolatrendszer), melyet az átlagosnál lényegesen ritkábban említenek a vállalkozások.

Az egyes városok vonatkozásában külön-külön is megvizsgáltuk a telephelyi tényezők abszolút értékeinek 2004-2005-höz mért változását. Ahogy az a 4. ábrán látható, Pécs telephelyi sikerességének korábbi magyarázatai közül kettő, az innovációs kultúra és a lakóhelyi környezet minősége megmaradt, a város felkészült munkaereje és kedvező müködési költsége viszont már kikerült a legfontosabb indokok sorából (Mivel előző kutatásunk szempontrendszerét még tíz tényező alkotta, két új tényezőnk, a demográfiai és társadalmi adottságok, valamint a település nemzetközi kapcsolatrendszere nem szerepel ábránkon.). Az országos válaszok alapján a város ma elsősorban még közintézményi ellátottságának és üzleti szolgáltatásainak köszönheti kedvező megítélését. Pécs saját régióján belüli megítélése valamennyi tényező esetében kismértékben javult, a leggyakoribb indokként a közintézményi ellátottság, az üzleti szolgáltatások és az innovációs kultúra szerepel. (Korábban a dél-dunántúli vállalatok még a munkaerő képzettségét és a lakóhelyi környezetet is idesorolták.) 
Amennyiben egyidejűleg megvizsgáljuk az egyes telephelyi tényezők eltérő jelentőségét, valamint a részletes vizsgálat tárgyává tett városok differenciáit, kijelenthető, hogy Pécs esetében (hasonlóan Debrecen, Szeged és Miskolc városokhoz) a válaszadók kevesebb és egyben kevésbé fontos tényezőkkel indokolják a település sikerességét, mint teszik azt Győr, Budaörs vagy éppen Székesfehérvár esetében. (Hasonló megállapításra jut LUX (2013) három nagyvárosi térséget, Pécset, Miskolcot és Győrt elemző kutatásában.)

Második hipotézisünk csak részben teljesült, mivel a sorrendben hátrébb szereplő városok (kiemelten Budaörs, másodsorban Veszprém) az általunk vártnál komplexebb tényezőkínálatot biztosítanak. Pécs az előzetesen várt tényezők közül kettő esetében mutat kiemelkedő értéket (környezeti minőség, innovációs kultúra), míg a munkaerő felkészültsége és hatékonysága az átlagosnál ritkábban fordul elő a város sikerességi magyarázatai között.

4. ábra: Pécs megítélése a magyar vállalatok megkérdezése alapján, 2016-2017

(a válaszok százalékában kifejezve, $n=1000$ )

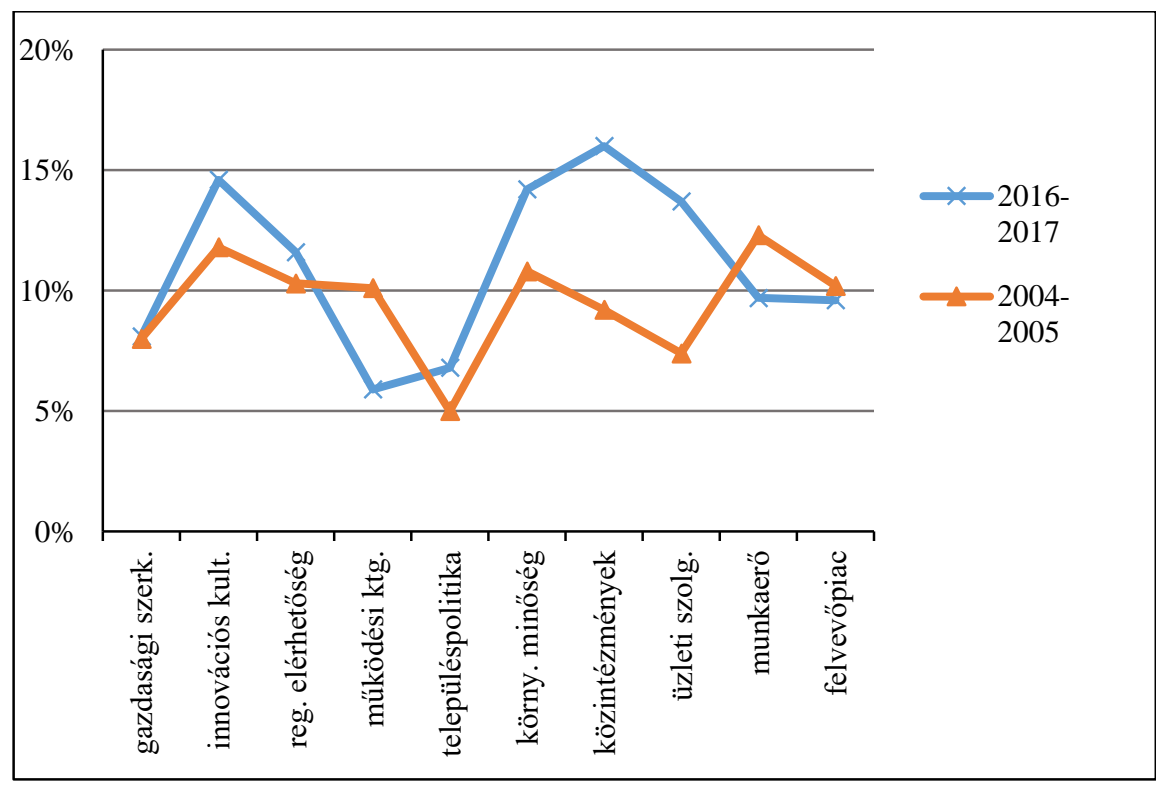

Forrás: Saját kérdőives felmérés (2004-2005, 2016-2017)

\subsection{Központok a vállalati vélemények tükrében}

Kutatásunk következő kérdése arra irányult, hogy a vállalatok mely településeket tartják valódi vonzásközpontoknak ma Magyarországon. Korábbi eredményeink alapján Budapest az ország valamennyi régiójában megjelent központként, ráadásul az ország öt régiójában a fôvárost említették legtöbbször, mint centrumot. A kivételt jelentő Dél-Dunántúlon 2004-2005-ben még Pécs számított elsődleges vonzásközpontnak, míg az Észak-Alföldön Debrecent jelölték meg ekkor a legtöbben. Harmadik hipotézisünk szerint a vállalatvezetők továbbra is valamennyi régióban meghatározó központként tekintenek Budapestre. Számítottunk Győr és Kecskemét központi szerepkörének országos felértékelődésére, míg Pécs megítélése elsősorban a DélDunántúlon kedvező.

A dél-dunántúli vállalatok szerint az elsődleges központ mára már Budapest, Pécs mellett Kaposvár került még megemlítésre. Pécs és Kaposvár elsősorban széleskörü üzleti szolgáltatásainak, másodsorban felvevőpiacának köszönheti központ jellegét. (Szeged és Pécs esetében joggal hiányolhatjuk a centrumfunkció magyarázatai sorából az innovációs kultúrához, kutatás-fejlesztési kapacitáshoz kapcsolódó szempontot, ami újfent ennek a tényezőnek a kevésbé meghatározó jelentőségét mutatja.) 
Közép-Magyarország válaszadói korábban a fóváros mellett Székesfehérvárt is a vonzásközponti jelentőségü városok közé sorolták, jelenleg Budapest után már Kecskemétet nevesítették itt a legtöbben. A főváros elsődlegesen széleskörű üzleti szolgáltatásainak köszönheti centrumfunkcióját, amit közintézményi ellátottsága, kedvező közlekedési infrastruktúrája, valamint felvevőpiaci jellege és előnyös gazdasági szerkezete tovább erősít. Aktuálisan továbbra is Budapest az első számú vonzásközpont a Dél-Alföldön, melyet Kecskemét és Szeged követ. Mindkét dél-alföldi város mind üzleti szolgáltatásaik, mind közintézményi ellátottságuk, mind beszerzési és értékesítési szerepkörük miatt központoknak minősülnek. Az Észak-Alföldön Budapestet Debrecen és Szolnok követi. Debrecent föleg kedvező gazdasági szerkezete, beszállítói kapcsolatrendszere kapcsán nevesítik, míg Szolnok üzleti szolgáltatásai okán került a centrumok sorába. (Debrecennél a megelőző kérdések során hangsúlyosnak számító tényezők, így az üzleti szolgáltatások, a közintézményi ellátottság vagy a felvevőpiaci jelleg ezúttal ritkábban szerepelnek.) A soron következő három régióban nem Budapest, hanem az adott régión belüli városok szerepelnek elsődleges vonzásközpontként. A Közép-Dunántúlon Székesfehérvárt több vállalat gondolja központnak, mint Budapestet. Teszik ezt üzleti szolgáltatásai, közlekedési infrastruktúrája, közintézményi ellátottsága, kedvező gazdasági szerkezete okán. Másodsorban a város innovációs kultúrája és felvevőpiaci jellege is a magyarázatok között szerepel. Észak-Magyarországon Miskolcot jelölték meg a legtöbben, Eger valamivel ritkábban szerepel a válaszokban. Miskolcot elsődlegesen üzleti szolgáltatásai miatt nevesítik a régió vállalatai, másodsorban közintézményeinek, gazdasági szerkezetének és közlekedési infrastruktúrájának köszönheti centrumfunkcióit. Egernél a közintézményi ellátottság szolgál magyarázatul. (Miskolc esetében a regionális válaszokban említett felvevőpiaci jelleg ezúttal kevésbé hangsúlyos.) Végül a Nyugat-Dunántúlon nem csak Győr, hanem a régió másik két megyeszékhelye, Szombathely és Zalaegerszeg is több említést kapott centrumként, mint Budapest. Elsődlegesen üzleti szolgáltatásaik, közintézményi ellátottságuk, valamint közlekedési infrastruktúrájuk okán. (Győr esetében, hasonlóan Szegedhez és Pécshez, az innovációs kultúra, kutatás-fejlesztési kapacitás magyarázó szerepe ritkábban jelenik meg.)

Hipotézisünk megerősítést nyert, mivel Budapest vonzásközpont jellege valamennyi régióban kimutatható, Győr, Kecskemét és Pécs pedig elsősorban saját régióján belül tudta megerősíteni, megtartani centrumfunkcióit.

\section{Következtetések}

A magyar települések telephelyi sikerességének magyarázatai között felértékelödőben vannak gazdasági adottságaik, földrajzi elhelyezkedésük, megközelíthetőségük, infrastrukturális ellátottságuk, humán erőforrásaik képzettsége és helyi fejlesztéspolitikai aktivitásuk. Az általunk elemzett telephelyi tényezők közül a müködési helyszín kijelölésében az átlagosnál nagyobb mértékben nőtt a helyi önkormányzat településpolitikájának, a müködési költségeknek, a munkaerő felkészültségének, a település innovációs kultúrájának és környezeti minőségének a magyarázó ereje. Amellett, hogy a magyar vállalkozások költségérzékenyebbé váltak, egyidejüleg fontosabbá vált számukra a felkészült munkaerő megléte, ami egyértelműen visszavezethető a munkaképes korúak számbeli csökkenésére és a vizsgált időszakban tapasztalható szükülö kvalifikált munkakínálatra. Közép- és nagyvállalati körben valamivel meghatározóbb az innovációs kultúra magyarázó ereje, még fontosabbak a müködési költségek és a minőségi munkaerő, míg a vállalati méret növekedésével párhuzamosan veszít jelentőségéből a település felvevőpiaci jellegének és környezeti minőségének magyarázó szerepe. A területi versenyképesség erős hierarchikus meghatározottsága okán közép- és nagyvárosaink vonzása részben ellensúlyozhatja kedvezőtlen földrajzi fekvésüket is, amit jól mutat, hogy nagyvárosok, főként régió- és megyeközpontok kerültek országos és regionális telephelyi rangsoraink élére. Pécs valamelyest rontott 2004-2005-ös pozíciójához képest, 
sikeres telephelyi magyarázatai az innovációs kultúrára, környezeti minőségre, közintézményi ellátottságra és az elérhető üzleti szolgáltatásokra korlátozódnak. A vállalatok szerint legmeghatározóbb tényezőknél gyengén teljesít, vonzásközponti szerepe csökken.

Az egyidejüleg lokalizált versenyelőnyökre épülő és erőteljes nemzetközi beágyazottságot biztosító, városhálózatokra alapozott fejlődés megteremtése komoly kihívások elé állítja vidéki nagy- és középvárosainkat. Fejlesztéspolitikai aspektusból mindez azért különösen sürgetö feladat, mivel az európai léptékben középvárosok hiánya miatt Budapest az egyetlen, amely jelentősebb, akár globális funkciók betöltésére is vállalkozhat, többi településünk egyelöre nem részese a nemzetközi városhálózatnak, gyakran tágabb környezetének dinamizálására sem alkalmas. A régóta vágyott policentrikus, magas adaptációs képességü, ezáltal fenntartható fejlödéssel szemben a külső függőségből, alacsony hozzáadott értékü gazdasági tevékenységekből származó kedvezőtlen adottságokat a munkaerőhiány és az emelkedő müködési költségek tovább erősítik. A többi hazai településhez hasonlóan, Pécsnek is ki kell jelölnie azt az elsősorban alulról szerveződő, térségi specializáción és endogén erőforrásokon alapuló fejlesztési stratégiát, mellyel hosszú távon biztosíthatóvá válik a város sikeres működése. Mivel a vidéki városok funkcionálisan gyengék és elmaradnak az elégséges méretgazdasági kritériumoktól, mindezt másokkal kooperálva, fejlesztő együttmüködések keretében célszerü megtenniük.

\section{Irodalomjegyzék}

BAKOS, N. - HIDAS, ZS. - KEZÁN, A. (2011): Területi különbségek Magyarországon. A főbb társadalmi és gazdasági folyamatok az ezredforduló után. Területi Statisztika (51)4: pp. 335-357.

BARANYAI, N. - BARÁTH, G. (2009): A várostérségek gazdasági és társadalmi versenyképességi rangsora. In: Szirmai, V. (szerk.): A várostérségi versenyképesség társadalmi tényezöi. Dialóg Campus, Budapest-Pécs. pp. 191-201.

BARTA, GY. (2000): A külföldi müködő tőke szerepe a magyar ipar duális struktúrájának és regionális differenciálódásának kialakulásában. In: Horváth, Gy. - Rechnitzer, J. (szerk.): Magyarország területi szerkezete és folyamatai az ezredfordulón. MTA RKK, Pécs. pp. 265281.

BERKI, M. - GONDA, T. (2006): A kulturális turizmus magyarországi városi helyszíneinek pozícionálása. Földrajzi Értesitö (55)1-2: pp. 127-140.

CSOMÓS, GY. (2013): Magyarország gazdasági központjainak pozícióváltozása 1992 és 2011 között. Területi Statisztika (53)6: pp. 529-550.

DÖBRÖNTE, K. (2018): A közép-európai városok pozíciója a magas szintü üzleti szolgáltatók lokációs döntéseiben. Területi Statisztika (58)2: pp. 200-219. https://doi.org/10.15196/TS580204

EGEDY, T. (2012): A gazdasági válság hatása a nagyvárosok versenyképességére Magyarországon. Földrajzi Közlemények (136)4: pp. 420-438.

ENYEDI, GY. (1996): Regionális folyamatok Magyarországon az átmenet idöszakában. Hilscher Rezső Szociálpolitikai Egyesület, Budapest.

HARCSA, I. (2015): A területi fejlettség és egyenlőtlenségek lehetséges értelmezései - kritikai értékelés és kutatási eredmények II. Statisztikai Szemle (93)6: pp. 521-551. 
HRUBI, L. (2000): A gazdasági térszerkezet változásai Magyarországon. In: Horváth, Gy. Rechnitzer, J. (szerk.): Magyarország területi szerkezete és folyamatai az ezredfordulón. MTA RKK, Pécs. pp. 237-264.

KISS, É. - JANKÓ, F. - BERTALAN, L. - MIKÓ, E. (2018): Nyugat és Kelet határán: Sopron a belföldi migrációban. Tér és Társadalom (32)4: pp. 151-166. https://doi.org/10.17649/TET.32.4.3070

KISS, J. P. - SZALKAI, G. (2014): A foglalkoztatás területi koncentrációjának változásai Magyarországon a népszámlálások ingázási adatai alapján, 1990-2011. Területi Statisztika (54) 5: pp. 415-447.

KOLTAI, Z. (2019): Magyarországi gazdasági központok és mobilitási hajlandóság a telephelyi tényezök tükrében. Földrajzi Közlemények (143)4: pp. 324-338.

KOLTAI, Z. (2014): Sikeres és versenyképes városok, Piackutatás a magyar települések körében. PTE FEEK, Pécs.

KOLTAI, Z. (2007): A magyarországi városok versenyképességének vállalati megítélése. Tér és Társadalom (21)2: pp. 23-42. https://doi.org/10.17649/TET.21.2.1106

KOLTAI, Z. (2006): A magyar lakosság és vállalati szféra lakó-, illetve telephelyválasztásának szempontjai. Területi Statisztika (46)3: pp. 240-254.

KOLTAI, Z. - FILÓ, CS. (2021a): A hazai nagyvárosok sikerességének tényezői a vállalati vélemények tükrében. Tér és Társadalom (35)1: pp. 92-112. https://doi.org/10.17649/TET.35.1.3213

KOLTAI, Z. - FILÓ, CS. (2021b): A magyarországi városok telephelyi tényezőinek vállalati megítélése. Területi Statisztika (61)1: pp. 79-104. https://doi.org/10.15196/TS610104

KONCZOSNÉ SZOMBATHELYI, M. (2014): A regionális és a vállalati kultúra kölcsönhatásának vizsgálata. Tér és társadalom (28)1: pp. 84-98.

KOZMA, G. (1998): A gazdasági élet szereplőinek térbeli preferenciái. Falu Város Régió (5)9: pp. 7-14.

LENGYEL, I. (2012): A kelet-közép-európai országok régióinak versenyképessége. In: Rechnitzer, J. - Smahó, M. (szerk.): Jármüipar és regionális versenyképesség. Nyugat- és Közép-Dunántúl a kelet-közép-európai térségben. Széchenyi University Press, Győr. pp. 191229.

LENGYEL, I. - RECHNITZER, J. (2000): A városok versenyképességéről. In: Horváth, Gy. Rechnitzer, J. (szerk.): Magyarország területi szerkezete és folyamatai az ezredfordulón. MTA RKK, Pécs. pp. 130-152.

LENGYEL, I. - VARGA, A. (2018): A magyar gazdasági növekedés térbeli korlátai helyzetkép és alapvető dilemmák. Közgazdasági Szemle (65)5: pp. 499-524. https://doi.org/10.18414/KSZ.2018.5.499

LUX, G. (2013): Kritikus tömeg alatt: a fejlesztési együttmüködés lehetőségei a kisebb nagyvárosokban. Tér és Társadalom (27)4: pp. 52-74. https://doi.org/10.17649/TET.27.4.2512

MAKRA, L. - SÜMEGHY, Z. (2010): Magyarországi városok és megyék osztályozása infrastrukturális és környezeti indikátorok alapján. Földrajzi Közlemények (134)2: pp. 203-215.

MÁTÉ, É. (2017): Perforált régiók? - Izolálódó térségek a Dél-Dunántúlon. Földrajzi Közlemények (141)2: pp. 164-178. 
MOLNÁR, E. - DÉZSI, GY. - LENGYEL, I. M. - KOZMA, G. (2018): Vidéki nagyvárosaink gazdaságának összehasonlító elemzése. Területi Statisztika (58)6: pp. 610-637. https://doi.org/10.15196/TS580604

NAGY, E. - NAGY, G. (2008): A városok gazdasági potenciálja. Falu Város Régió (15)3: pp. $32-42$.

NAGY, G. (1995): A külföldi tőke szerepe és térbeli terjedése Magyarországon. Tér és Társadalom (9)1-2: pp. 55-82.

PAP, N. - GONDA, T. - RAFFAY, Z. (2013): Pécs, a possible gateway city. Forum Geografic (12)2: pp. 178-186.

PÉNZES, J. - MOLNÁR, E. - PÁLÓCZI, G. (2014): Helyi munkaerő-piaci vonzáskörzetek az ezredforduló utáni Magyarországon. Területi Statisztika (54)5: pp. 474-490.

RECHNITZER, J. (2019): Nagyvárosok a magyar területi politikában és területfejlesztésben a rendszerváltozástól napjainkig. Tér és Társadalom (33)1: pp. 3-26. https://doi.org/10.17649/TET.33.1.3069

RECHNITZER, J. (1998): A privatizáció regionális összefüggései. Kulturtrade, Budapest.

RECHNITZER, J. - BERKES, J. - FILEP, B. (2019): The most important city development initiatives of Hungary. Regional Statistics (9)2: pp. 20-44. https://doi.org/10.15196/RS090204

RECHNITZER, J. - CSIZMADIA, Z. - GROSZ, A. (2004): A magyar városhálózat tudásalapú megújító képessége az ezredfordulón. Tér és Társadalom (18)2: pp. 117-156.

RECHNITZER, J. - PÁTHY, Á. - BERKES, J. (2014): A magyar városhálózat stabilitása és változása. Tér és Társadalom (28)2: pp. 105-127. https://doi.org/10.17649/TET.28.2.2623

SEBESTYÉNNÉ SZÉP, T. - SZENDI, D. - NAGY, Z. - TÓTH, G. (2020): A gazdasági reziliencia és a városhálózaton belüli centralitás közötti összefüggések vizsgálata. Területi Statisztika (60)3: pp. 352-369. https://doi.org/10.15196/TS600303

SZAKÁLNÉ KANÓ, I. - KAZEMI-SÁNTA, É. - LENGYEL, I. (2017): Territorial distribution of highly educated individuals in Hungary after 1990. Regional Statistics (7)2: pp. 171-189. https://doi.org/10.15196/RS070209

SZIRMAI, V. (2017): Az új városi urbanizációs modell szocialista és/vagy globális természete. Tér és Társadalom (31)3: pp. 25-43. https://doi.org/10.17649/TET.31.3.2861

VARGA, V. - TEVELI-HORVÁTH, D. - SALAMIN, G. (2020): A fiatal, képzett lakosságot vonzó potenciál a Budapest körüli csapágyvárosokban. Területi Statisztika (60)2: pp. 179-210. https://doi.org/10.15196/TS600204 